\title{
THE INFLUENCE OF GLUCOSE, FRUCTOSE, AND INSULIN ON THE METABOLISM OF LEUKOCYTES OF HEALTHY AND DIABETIC SUBJECTS ${ }^{1,2}$
}

\author{
By SAMUEL P. MARTIN, GORDON R. MCKINNEY, R. GREEN, \\ AND CAROLINE BECKER 4 \\ (From the Departments of Medicine, of Bacteriology, and of Physiology and Pharmacology, \\ Duke University School of Medicine, Durham, N. C.)
}

(Submitted for publication April 21, 1953; accepted July 8, 1953)

The in vitro influence of glucose, fructose, and insulin on human leukocytes of healthy and diabetic subjects was measured as a part of a study of the metabolic behavior of these cells, and an attempt was made to correlate metabolic alterations in leukocytes with resistance and susceptibility to infectious diseases. Previous workers have shown that leukocytes from alloxan diabetic rabbits are able to phagocytize but not destroy bacteria (1). Dubos has shown that lactate in the presence of low oxygen tension is bactericidal for M. tuberculosis (2). Human leukocytes produce lactic acid in the presence of oxygen, and the quantity is not changed markedly by decreased oxygen tension $(3,4)$. It has also been shown that these cells produced more lactate from glucose than from fructose, and that when the two sugars were added simultaneously the lactate production was additive. The effect of these hexoses and insulin was studied on leukocytes from normal and diabetic subjects. The responses after cell injury were also determined.

\section{METHODS}

Healthy subjects and subjects with moderately severe untreated diabetes mellitus were used as donors. The obese mild diabetics were excluded from this series. The blood was collected before breakfast. The white

1 This work is supported in part by a grant (G 3476) from the National Institutes of Health, Public Health Service, the Atomic Energy Commission Contract No. AT (40-1) 1081 and the Baxter Laboratories, Inc.

2 A part of this work was presented at the Southern Society for Clinical Investigation and American Federation for Clinical Research, January 29-30, 1953, New Orleans, La.

8 Fellow of the American Cancer Society, recommended by the Committee on Growth, National Research Council.

4 Public Health Service Post-doctorate Research cells were prepared for study by a method previously described (4). This consisted of the processing of the cells in a non-wetting system without exposure to excessive gravitational forces. The blood was drawn from the cubital vein into a plastic bag ${ }^{5}$ or siliconed syringe. Dowex 50 or heparin $(0.02 \mathrm{mg}$. per $\mathrm{ml}$.) was used as an anticoagulant. Dextran, ${ }^{6}$ in a final concentration of one per cent, was added to induce rouleaux formation and rapid sedimentation of the red cells. The white cells in the supernatant plasma were concentrated by centrifugation for 7.5 minutes at $50 \times \mathrm{G}$. The cells were resuspended by gentle agitation in a buffered saline solution. 7 Sufficient buffer was added to obtain a cell count of 30,000 to 50,000 cells per cu. mm. In order to study the broken cells, the resuspended preparations were counted and recentrifuged at $400 \times \mathrm{G}$ for twenty minutes. This cell mass was ground in a mortar with alumina gel, filtered through cheese cloth, and again suspended for metabolic studies. Alumina gel was used because this system caused destruction of 90 per cent of the cells. Previous studies showed this material prepared in this manner had Krebs cycle activity (4).

The cells or brei were added to an equal volume of the buffered solution containing the hexose. The final cell counts were from 15,000 to 25,000 per cu. mm. and a total of 45,000 to 75,000 cells per vessel. The reaction mixtures were placed in $25 \mathrm{ml}$. Erlenmeyer flasks in a constant temperature water bath $\left(37^{\circ}\right.$ C. $)$ and shaken at ten oscillations a minute for four hours. Before and after incubation, lactic acid determinations were done by the method of Barker and Summerson (5). The values were expressed as micromoles of lactic acid produced by ten million white cells in an hour. The methods of Somogyi (6) and Roe as described by Umbreit,

5 Fenwal Blood Pack, Fenwal Laboratories, Framingham, Mass.

- Pyrogen free dextran, intrinsic viscosity 0.46 , obtained from Pharmacia Ltd., Uppsala, Sweden.

${ }^{7}$ Solution prepared by diluting $10 \mathrm{ml}$. of Stock A and $7.0 \mathrm{ml}$. of Stock B in $100 \mathrm{ml}$. sterile non-pyrogenic water. One liter of Stock A contains $75.0 \mathrm{Gm}$. NaCl, $7.5 \mathrm{Gm} . \mathrm{KCl}, 1.0 \mathrm{Gm}$. $\mathrm{Na}_{2} \mathrm{HPO}_{4}, 1.2 \mathrm{Gm} . \mathrm{KH}_{2} \mathrm{PO}_{4}$, and $0.5 \mathrm{Gm}$. K $\mathrm{K}_{2} \mathrm{HPO}_{4}$. Stock B contains $10.0 \mathrm{Gm}$. Nas HPO. in one liter. The hexose solutions and non-pyrogenic distilled water were supplied by Baxter Laboratories, Morton Grove, Illinois. 
Burris, and Stauffer (7) were used for glucose and fructose analyses and the values were converted to the micromoles of glucose utilized by ten millon cells in one hour. In the usual experiment, the final concentration of insulin was $0.1 \mathrm{u}$ per $\mathrm{ml} .^{8}$ In a group of healthy and diabetic subjects, the response of the cells to insulin with $100 \mathrm{mg}$. per cent of glucose or fructose was measured.

\section{RESULTS}

The results of the experiments on intact and broken leukocytes from healthy subjects are graphically outlined in Figure 1. At low hexose concentration, the production of lactate was proportional to the concentration of the sugar. With glucose, there was a sharp increase with a peak at 50 to $80 \mathrm{mg}$. per cent hexose, depending on the total number of cells. As the concentration was increased above $100 \mathrm{mg}$. per cent, there was a decrease in lactate production. With fructose, the increase in lactate production was less rapid and remained linear until a concentration of $300 \mathrm{mg}$. per cent was reached. In the broken cells, the response to the two hexoses was qualitatively and quantitatively similar. When the sugars were

8 Insulin obtained from Eli Lilly Co., Indianapolis, Ind.

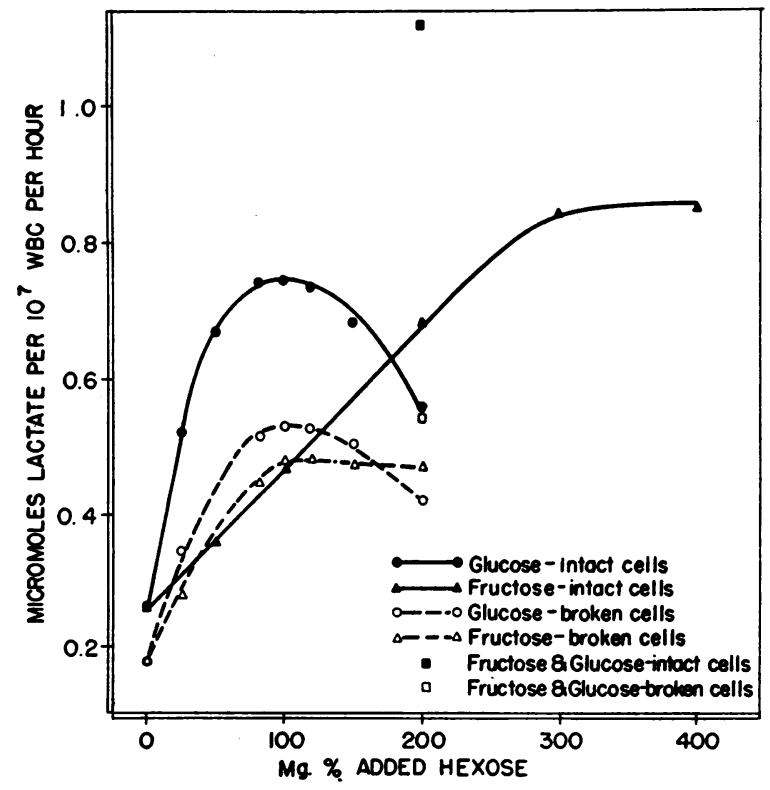

Fig. 1. The Effect of Glucose and Fructose on the Aerobic Production of Lactic Acid by Leukocytes from Healthy Subjects

Curves represent a composite of duplicate determinations on seven subjects. added simultaneously, their effects were additive in the intact cell but not in the broken cell.

The utilization of glucose and fructose was measured in the intact leukocyte when the concentration of glucose was $100 \mathrm{mg}$. per cent, the fructose was $100 \mathrm{mg}$. per cent, and when the two sugars at this concentration were mixed. When the two sugars were mixed, the production of lactate was a summation of the two alone. The utilization of the hexoses, however, was markedly altered. The utilization of glucose when separate was $0.24 \pm$ 0.09 (SE) micromole per 10 million cells per hour for glucose and when added with fructose was $0.46 \pm 0.16$. The fructose utilization under similar conditions was $0.16 \pm 0.02$ micromole per 10 million cells per hour and when glucose was added dropped to $0.04 \pm 0.005$.

The experiments with intact cells from normal and diabetic subjects with $100 \mathrm{mg}$. per cent of glucose and fructose, as well as the effect of insulin in the presence of glucose, are presented in Table I. The cells of the diabetic subject have a significantly lower ( $p$ 0.01) production of lactic acid with glucose and a significantly higher ( $p 0.01)$ production with fructose. This is in contrast to the normal cell. With the addition of insulin, there was a significant increase in the lactate production in the diabetic subject with no response in the control group. Data not included in the table indicated that insulin was effective in concentrations as low as $0.01 \mathrm{u}$ per $\mathrm{ml}$. and did not influence the lactate production in the presence of fructose. Injury or destruction of the cell membrane abolished the insulin response.

The utilization of glucose was significantly lower in the diabetic than in the control group ( $p$ 0.02). There was a significant increase ( $p 0.02$ ) in utilization of glucose in the diabetic group ( $0.18 \pm$ 0.04 micromole) on the addition of insulin. This brought the value for diabetic leukocytes to the normal range. Insulin did not affect the glucose utilization of the normal leukocyte at $100 \mathrm{mg}$. per cent level when $0.1 \mathfrak{u}$ insulin was used.

\section{DISCUSSION}

The data presented would indicate that the lactate production of human leukocytes was proportional to the hexose utilization and may be determined by the ability of the cell to transport the 
TABLE I

The influence of glucose, fructose, and insulin on human leukocytes from normal and diabetic subjects (The mean and standard error of micromoles of lactate produced or glucose utilized per ten million cells per hour)

\begin{tabular}{|c|c|c|c|c|}
\hline Subject & Substrate & $\begin{array}{c}\text { Micromoles } \\
\text { lactate } \\
10 M W B C / h r .\end{array}$ & $\begin{array}{l}\text { Change on } \\
\text { addition } \\
\text { of insulin }\end{array}$ & $\begin{array}{c}\text { Micromoles } \\
\text { glucose } \\
10 M W B C / h r .\end{array}$ \\
\hline $\begin{array}{l}\text { Control } \\
9 \text { subjects }\end{array}$ & $\begin{array}{l}100 \mathrm{mg} . \% \text { glucose } \\
100 \mathrm{mg} . \% \text { fructose }\end{array}$ & $\begin{array}{l}0.55 \pm 0.05 \\
0.38 \pm 0.03\end{array}$ & $\begin{array}{c}+0.003 \pm 0.01 \\
(p 0.10)\end{array}$ & $0.20 \pm 0.02$ \\
\hline $\begin{array}{l}\text { Diabetes mellitus } \\
22 \text { subjects }\end{array}$ & $\begin{array}{l}100 \mathrm{mg} . \% \text { glucose } \\
100 \mathrm{mg} . \% \text { fructose }\end{array}$ & $\begin{array}{l}0.42 \pm 0.03 \\
0.54 \pm 0.01\end{array}$ & $\begin{array}{c}+0.092 \pm 0.03 \\
(\mathrm{p} \mathrm{0.02)}\end{array}$ & $0.12 \pm 0.03$ \\
\hline
\end{tabular}

sugar across the cell membrane. The differences in response of leukocytes in the control group to glucose and fructose could be due to different mechanisms of absorption. This could be through a separate transport mechanism, different affinity for the sugars by the same mechanism, or through variations in cell permeability. Cori and Slein (8) reported a glucokinase and fructokinase in rabbit muscle. Meyerhof and Wilson (9) and Colowick (10) have described different affinities of one hexokinase for glucose and fructose. If this were the mechanism, in the present experiments at 100 mg. per cent, the ratio would be 2 to 1 , a figure close to that obtained for rat muscle and brain hexokinase by the above investigators. The work of Cori on absorption of hexoses from the small intestine of rats also showed a similar ratio (11). The increased glucose utilization in the presence of fructose with a drop in fructose utilization cannot be explained. The behavior of the broken cells in these studies closely parallel the studies of Levene and Meyer $(12,13)$ on exudate leukocytes.

The absence of response to insulin in injured cells and the diminished response to glucose may be related. Previous work with similar preparations of leukocytes had shown that destruction of the cell integrity will also interfere with the action of hydrocortisone, a hormone which diminishes the utilization of glucose and the production of lactate by intact leukocytes (14).

Leukocytes from diabetic subjects produce less lactate in the presence of glucose. The studies of Tolstoi (15) showed no difference in glucose utilization of whole blood, but these were carried out with a different cell population, the red cell being the predominant cell. The erythrocyte and leukocyte might not have the same mechanisms of sugar transport or lactate formation. The diabetic white cell retains the ability to respond to fructose. This is comparable with the in vivo effects noted by Root, Stotz, and Carpenter on oral feeding (16) and more recently by Miller and his co-workers after intravenous infusion (17).

The normal leukocyte showed no response to insulin. Eadie, Macleod, and Noble (18) found that there was no response in glycolysis of whole blood of normal animals after the addition of insulin. Macleod (19) reported similar findings in sterile exudate leukocytes of normal animals. The present results indicate that the leukocyte of the diabetic subject responds to insulin by increasing lactate production. There has been a consistent discrepancy between the lactate produced and the glucose utilized. This is greater with the diabetic cells. The source of this lactate may not necessarily be through glycolysis in the complete Meyerhof-Emden System but may be through some other pathway such as that suggested by Cori (20). It may indicate the conversion of 3-phosphoglyceric aldehyde to methyl glyoxal and lactic acid as described in vitro by Meyerhof and Lohman (21). Work, currently in progress by McKinney (22), indicates the existence of glyoxylase in leukocytes.

The effect of the metabolic defect noted in the leukocytes from subjects with diabetes mellitus may account for the alterations in susceptibility to infection. Dubos (2) has shown that lactate in the presence of low oxygen tension has a very deleterious effect on the tubercle bacillus. In an area of inflammation, the leukocyte of the diabetic subject might be unable to utilize the available glucose to produce bactericidal quantities of lactic acid.

\section{SUMMARY}

Leukocytes from healthy individuals produce more lactic acid from glucose than from fructose, 
and fructose increases the glucose utilization. This difference is abolished by grinding the cells. Leukocytes from diabetic subjects produce more lactic acid from fructose than from glucose. In the healthy subject, insulin had no measured effect on the lactate production of the cell; while in the diabetic, it produced a significant increase in lactate formation with glucose but not with fructose. The utilization of glucose was significantly increased by insulin in the diabetic group but not in the control group. Cell injury blocked the hormone effect.

\section{REFERENCES}

1. Cruickshank, A. H., and Payne, T. P. B., Anti-pneumococcal powers of the blood in alloxan diabetes in the rabbit. Bull. Johns Hopkins Hosp., 1949, 84, 334.

2. Dubos, R. J., Effect of the composition of the gaseous and aqueous environment on the survival of tubercle bacilli in vitro. J. Exper. Med., 1953, 97, 357.

3. Kempner, W., The nature of leukemic blood cells as determined by their metabolism. J. Clin. Invest., 1939, 18, 291.

4. McKinney, G. R., Martin, S. P., Rundles, R. W., and Green, R., Respiratory and glycolytic activity of human leukocytes in vitro. J. Appl. Physiol., 1953, 5,335 .

5. Barker, S. B., and Summerson, W. H., The colorimetric determination of lactic acid in biological material. J. Biol. Chem., 1941, 138, 535.

6. Somogyi, M., A new reagent for the determination of sugars. J. Biol. Chem., 1945, 160, 61.

7. Umbreit, W. W., Burris, R. H., and Stauffer, J. F., Manometric Techniques and Tissue Metabolism, rev. ed., Minneapolis, Minn., Burgess Publishing Co., 1949, p. 191.

8. Cori, G. T., and Slein, M. W., Gluco- and fructokinase in mammalian tissues. Federation Proc., 1947, 6, 245.
9. Meyerhof, O., and Wilson, J., Studies on glycolysis of brain preparations. V. Affinity of hexokinase for glucose and fructose. Arch. Biochem., 1948, 19, 502.

10. Colowick, S. P., Transphosphorylating Enzymes of Fermentation, New York, in the Enzymes, Sumner, J. B., and Myrbäck, K., eds., Academic Press, Inc., 1951, vol. 2, part 1, p. 131.

11. Cori, C. F., The fate of sugars in the animal body. I. The rate of absorption of hexoses and pentoses from the intestinal tract. J. Biol. Chem., 1925, 66, 691.

12. Levene, P. A., and Meyer, G. M., The action of leukocytes on glucose. J. Biol. Chem., 1912, 11, 361.

13. Levene, P. A., and Meyer, G. M., On the action of leukocytes on some hexoses and pentoses. Third communication contribution to the mechanism of lactic acid formation from carbohydrates. J. Biol. Chem., 1913, 14, 149.

14. Martin, S. P., Chaudhuri, S. N., Green, R., and McKinney, G. R., The effect of adrenal steroids on aerobic glycolysis in human leukocytes. In manuscript.

15. Tolstoi, E., Glycolysis in bloods of normal subjects and diabetic patients. J. Biol. Chem., 1924, 60, 69.

16. Root, H. F., Stotz, E., and Carpenter, T. M., The respiratory quotient and blood pyruvate and lactate responses after oral ingestion of glucose and fructose in diabetes mellitus with and without insulin. Am. J. M. Sc., 1948, n.s., 211, 189.

17. Miller, M., Drucker, W. R., Owens, G. E., Craig, J. W., and Woodward, H., Jr., Metabolism of intravenous fructose and glucose in normal and diabetic subjects. J. Clin. Invest., 1952, 31, 115.

18. Eadie, G. S., Macleod, J. J. R., and Noble, E. C., Insulin and glucolysis. Am. J. Physiol., 1923, 65, 462.

19. Macleod, J. J. R., Carbohydrate Metabolism and Insulin, London, Longmans Green and Co. Ltd., 1926.

20. Cori, C. F., Mammalian carbohydrate metabolism. Physiol. Rev., 1931, 11, 143.

21. Meyerhof, O., and Lohman, K., Uber die enzmatische gleichgewichtsreaktion zwischen Hexosediphosphorsäure und Dioxyacetonphosphorsäure. Biochem. Ztschr., 1934, 271, 89.

22. McKinney, G. R., Unpublished results. 